\title{
STABILISASI BERBASIS ION EXCHANGE UNTUK MENINGKATKAN DAYA DUKUNG SUBGRADE DI KOTA DUMAI
}

\author{
Susy Srihandayani *1, Aidil Abrar ${ }^{2}$, Surya Indrawan ${ }^{3}$ \\ ${ }^{123}$ Program Studi Teknik Sipil Sekolah Tinggi Teknologi Dumai \\ Jl. Utama Karya II Kelurahan Bukit Timah Dumai \\ *Corresponding authors: susys3unand18@gmail.com
}

Received: 12 September 2019, Accepted: 20 September 2019

DOI: $10.31849 /$ siklus.v5i2.3236

\begin{abstract}
Abstrak
Kadar air tinggi dan organik yang terkandung pada gambut sangat berpengaruh terhadap daya dukung sebagai lapisan tanah dasar. Berbagai upaya telah dilakukan dengan perkuatan maupun modifikasi tanah secara fisik maupun kimia. Stabilisasi berbasis Ion Exchange dengan menggunakan Difa SS dan semen dapat menjadi pilihan untuk meningkatkan daya dukung tanah gambut. Penelitian ini bertujuan menganalisis pengaruh Difa SS dan semen dengan kadar tertentu terhadap tanah gambut. Dari pengujian propertis tanah, tanah gambut yang digunakan mengandung pasir dan lanau. Berbagai variasi campuran Difa SS, semen dan tanah gambut dilakukan dengan Trial and Error untuk mencapai nilai daya dukung tanah dan pengujian CBR (California Bearing Ratio) cara laboratorium dilakukan tanpa rendaman (unsoaked). Tes CBR dilakukan setelah 4 hari periode curing. Hasil penelitian menunjukkan bahwa nilai CBR dari tanah gambut kering dengan kadar air optimum $16 \%$ dan $\gamma_{\mathrm{dmax}}=0,79 \mathrm{gr} / \mathrm{cm}^{3}$ distabilkan menggunakan Difa SS $6 \%$ dan 4\% mencapai 45,29\%. Pengaruh campuran Difa SS dan semen terhadap tanah gambut yang mempunyai kadar air tinggi dapat mengurangi kadar air gambut tersebut dan meningkatkan daya dukung.
\end{abstract}

Kata Kunci : Tanah gambut, daya dukung, Difa SS, stabilisasi

\begin{abstract}
High and organic water content contained in peat is very influential on the carrying capacity of the subsoil. Various attempts have been made to strengthen and modify the soil physically and chemically. Ion Exchange based stabilization using Difa SS and cement can be an option to increase the carrying capacity of peat soils. This study aims to analyze the effect of Difa SS and cement with certain levels on peat soils. From soil property testing, the peat soils used contained sand and silt. Various variations of the Difa SS mixture, cement and peat soil were carried out with Trial and Error to achieve the carrying capacity of the soil and CBR (California Bearing Ratio) testing of the laboratory method carried out without
\end{abstract}


immersion (unsoaked). CBR test is done after 4 days curing period. The results showed that the CBR value of dry peat soil with an optimum water content of $16 \%$ and mdmax $=0.79 \mathrm{gr} / \mathrm{cm} 3$ was stabilized using Difa SS 6\% and $4 \%$ reaching 45.29\%. The effect of Difa SS mixture and cement on peat soils that have high water content can reduce the water content of the peat and increase the carrying capacity.

Keywords: Peat soil, carrying capacity, Difa SS, stabilisation

\section{A. PENDAHULUAN}

Tanah yang buruk tidak dapat menopang beban yang bekerja di atasnya. Pembangunan infrastruktur jalan membutuhkan daya dukung yang tinggi pada tanah.

Mempunyai kadar air yang tinggi, kompresibilitas yang tinggi dan daya dukung yang rendah adalah karakteristik dari tanah gambut.

Tanah gambut yang mempunyai daya dukung rendah membutuhkan proses stabilisasi untuk dapat memenuhi spesifikasi teknis perancangan konstruksi jalan raya. Penggunaan zat kimia menjadi pilihan untuk mendapatkan hasil yang lebih memuaskan. (Mochtar 2014)

Difa SS merupakan salah satu bahan stabilisasi berbasis Ion Exchange yang dapat meningkatkan daya dukung tanah. Bahan ini tidak bekerja sendiri, namun lebih mengefektifkan sementanah dengan melarutkan asam humus pada permukaan butiran tanah (Mahakarya 2012).

Disamping itu, semen Portland akan menjadi media perekat bila bereaksi dengan air yang kemudian memadat dan membentuk massa tanah keras (Andriani 2012).

Perawatan 14 hari tanah lempung murni dengan penambahan semen dan Difa SS menghasilkan nilai CBR sebesar 97,17\% (Muqorrobin 2018) .

Penelitian ini dilakukan untuk menganalisis pengaruh variasi penambahan Ion exchange terhadap nilai CBR tanah gambut. Kemudian menganalisis peningkatan daya dukungnya setelah distabilisasi menggunakan semen dan Difa SS.

\section{B. TINJAUAN PUSTAKA}

\section{Tanah Gambut}

Tanah Gambut (Peat) yang tergolong ada tanah ekspansif yaitu Tanah atau batuan yang memiliki potensi kembang susut akibat perubahan kadar air. (Srihandayani 2017)

Tanah ekspansif umumnya diakibatkan oleh perubahan kadar air sehingga menyebabkan perubahan volume tanah. Tanah ekspansif merupakan jenis tanah yang bermasalah dalam suatu proyek konstruksi khususnya untuk pekerjaan timbunan tanah dasar suatu bangunan. Dengan perubahan volume tanah akibat kadar air yang rendah dapat mengakibatkan penurunan pada bangunan di atasnya (Settlement) terlebih jika penurunannya tidak seragam (Non-uniform Settlement). Penurunan tersebut dapat terjadi pada masa konstruksi maupun selama operasional bangunan tersebut. Selain penurunan, akibat kadar air yang tinggi dalam tanah dapat pula mengakibatkan tanah mengembang sehingga dapat menyebabkan bangunan terangkat (Uplift).

\section{Pemadatan Tanah}

Pengujian pemadatan adalah proses merapatkan butiran tanah secara mekanis yang menyebabkan keluarnya udara dari ruang pori, sehingga 
meningkatkan kepadatan tanah. Cara mekanis yang dipakai untuk pemadatan tanah bisa bermacam macam. (Pirmadona 2015)

Dilapangan biasanya di pakai cara penggilasan, sedangkan di laboratorium dipakai cara penumbukan atau pemukulan dengan menggunakan alat penumbuk standard.

Beberapa faktor yang mempengaruhi pemadatan, yaitu: kadar air merupakan pengaruh terbesar terhadap tingkat kepadatan yang dapat dicapai oleh suatu tanah. Jenis tanah yang diwakili oleh distribusi ukuran, bentuk butiran tanah, berat spesifik bagian padat tanah serta jenis mineral lempung yang ada pada tanah mempunyai pengaruh besar terhadap harga volume kering maksimum dan kadar air optimum dari tanah tersebut. Kadar air optimum adalah kadar air dimana harga berat volume kering maksimum tanah dicapai. Usaha /Energi pemadatan tanah diberikan mempengaruhi pemadatan, karna apabila usaha pemadatan persatuan volume berubah, maka kurva pemadatan juga akan berubah. Sehingga apabila energi pemadatan bertambah, harga berat volume kering maksimum tanah hasil pemadatan juga bertambah sedangkan kadar air optimumnya berkurang. (Nugroho 2012)

\section{California Bearing Ratio (CBR)}

CBR adalah perbandingan antara beban penetrasi suatu bahan terhadap beban penetrasi bahan standar dengan kedalaman dan kecepatan penetrasi tertentu, dan dinyatakan dengan persen. Pengujian CBR digunakan untuk menilai kekuatan tanah dasar atau bahan lain yang hendak dipakai untuk pembuatan suatu perkerasan. Nilai CBR yang diperoleh kemudian dipakai untuk menentukantebal lapisan perkerasan yang diperlukan di atas lapisan yang nilai CBR-nya ditentukan. Jadi dianggap bahwa pada suatu bahan dengan nilai CBR tertentu, perkerasannya tidak boleh kurang dari suatu angka tertentu.(Nugroho 2012)

Harga CBR dihitung pada harga penetrasi 0,1 sampai 0,2 ' dengan cara membagi beban pada penetrasi ini masing masing 6,9 dan 10,3 $\mathrm{MPa}$. Beban ini adalah beban standar yang diperoleh dari pengujian terhadap macam bauan percobaan (standar material) yang dianggap mempunyai CBR 100\%. CBR dapat ditentukan dengan menggunakan persamaan:

$$
=\frac{\text { Benda dalam Pengujian }}{\text { Beban Standar }} \times 100 \%
$$

Pengujian CBR di laboratorium dilaksanakan dengan dua macam metode yaitu CBR laboratorium rendaman (Soaked) untuk sampel tanah dengan kadar air rendah dan CBR laboratorium tanpa rendaman (Unsoaked) untuk kadar tinggi.

\section{Stabilisasi Tanah berbasis Ion Exchange}

Dalam pengertian luas, yang dimaksud stabilisasi tanah adalah pencampuran tanah dengan bahan tertentu, guna memperbaiki sifat sifat teknis tanah, atau dapat pula, stabilitas tanah adalah usaha untuk merubah sifat sifat teknis tanah agar memenuhi syarat teknis tertentu. Guna merubah sifatsifat teknis tanah seperti: kapasitas dukung, kompresibilitas, permeabilitas, kemudahan dikerjakan, potensi pengembangan dan sensitifitas terhadap perubahan kadar air, maka dapat dilakukan dengan cara penanganan dari yang paling mudah, seperti pemadatan sampai teknik yang lebih mahal, seperti mencampur tanah dengan semen, kapur, abu terbang, injeksi semen (grouting) dan pemanasan dan lain lain. Dalam pembangunan perkerasan jalan, 
stabilisasi tanah didefinisikan sebagai perbaikan material lokal yang ada, dengan cara stabilisasi mekanis atau dengan cara menambahkan suatu bahan tambah (additive) ke dalam tanah.(Tifani 2019)

Beberapa stabilisasi tanah yang telah dilakukan dengan metode Ion Exchange seperti Perbaikan tanah lempung ekspansif di lakukan dengan penambahan garam dapur $\mathrm{NaCl}$, hasil yang didapat dari pengujian sifat fisik tanah terjadi penurunan setelah di stabilisasi, dan malah sebaliknya pada pengujian mekanis mengalami peningkatan nilai CBR pada komposisi $50 \% \quad \mathrm{NaCl}$ terhadap berat tanah.(Sudjianto 2007)

Stabilisasi tanah menggunakan Portland Cemen Type I juga pernah dilakukan dengan hasil, terjadi peningkatan nilai CBR pada tanah lempang dengan penambahan $20 \%$ dari berat tanah kering dengan waktu perendaman 3 hari.(Andriani 2012)

PT. Difa Mahakarya dengan nama produk DIFA Soil Stabilizer (SS). Difa merupakan bahan aditif yang berfungsi memadatkan (solidifikasi) dan menstabilkan (stabilizer), Prinsip kerja komponen DIFA SS adalah dengan menyisihkan mineral yang berada pada permukaan partikel tanah. (Mahakarya 2012)

Mengurangi kadar air yang terkandung pada tanah dasar (Subgrade) Kandungan DIFA SS dipilih dari material anorganik yang memiliki energi ikatan Ion lebih besar dibandingkan dengan materi logam yang berada pada permukaan butiran tanah. Dari hasil penelitian sebelumnya, campuran semen tanah mampu meningkatkan kuat tekan hingga 200\% dibandingkan dengan kuat tekan tanah tanpa campuran semen. Nilai CBR maksimum yang tercapai dengan menggunakan DIFA SS bisa dicapai hingga 200\%. Dengan kemampuan seperti ini sudah cukup untuk membuktikan betapa DIFA berpengaruh cukup besar dalam peningkatan kualitas jalan. Tidak hanya itu, harganya yang ekonomis cukup untuk memangkas biaya pembangunan proyek jalan secara signifikan. Permasalahan sering terjadi saat musim hujan dengan kondisi basah dimana CBR turun drastis sehingga praktis tidak lagi dapat dilewati. Perkerasan dengan DIFA akan menjadikan tanah bermasalah saat musim hujan tetap solid untuk digunakan. DIFA Soil Stabilizer berfungsi mengoptimalkan stabilisasi tanah semen.

Mekanisme kerja Stabilisasi tanah DIFA dengan melarutkan asam humus pada permukaan butiran tanah, mengakibatkan semen dapat mengikat kuat pada partikel tanah. Disisi lain komponen pembangun Stabilisasi Tanah DIFA akan membentuk kristal-kristal tiga dimensi yang kokoh. (Mahakarya 2012)

Untuk ketebalan lapisan yang sama, Lapis perkerasan DIFA SS memiliki kinerja yang lebih baik dari pada lapis perkerasan agregat. Seperti hasil penelitian DIFA SS dengan tanah timbun dan semen untuk ketebalan timbunan $25 \mathrm{~cm}$ lapis perkerasan memiliki tiga kali lapis perkerasan agregat. Sangat memungkingkan penggunaan lapisan jalan DIFA SS yang lebih tipis untuk beban lalu lintas dan umur desain yang sama.

Perbandingan antara lapis perkerasan konvensional yang menggunakan batu pecah untuk LPA LPB dan lapis jalan DIFA SS, Untuk beban lalu lintas dan umur desain yang direncanakan jika menggunakan lapis perkerasan konvensional maka dibutuhkan LPA setebal $20 \mathrm{~cm}$ (CBR 90\%) dan LPB setebal $30 \mathrm{~cm}$ (CBR 
60\%), sedangkan jika menggunakan lapis perkerasan jalan Difa SS dengan nilai CBR $100 \%$ hanya membutuhkan ketebalan $20 \mathrm{~cm}$. (Mahakarya 2012)

(Kristiadi and Marzuko 2016) mengemukakan dengan penambahan Difa SS sifat fisik tanah mengalami perubahan yang signifikan menjadi lebih baik dibandingkan tanah asli sebelum di stabilisasi, dan peningkatan nilai CBR dipengaruhi oleh masa pemeraman dan persentase bahan tambah.

\section{METODE PENELITIAN}

Untuk memperoleh hasil yang diinginkan, penelitian ini dimulai dengan studi literatur, survei lokasi, serta persiapan alat dan bahan pengujian. Sampel tanah yang digunakan yaitu berupa tanah gambut yang berasal dari daerah Pelintung, Dumai Riau.

Variasi penggunaan bahan dengan cara mencampur tanah gambut yang sudah dibersihkan dari akar akar tanaman, dikeringkan dengan cara dijemur.

Tabel 1. Variasi campuran tanah gambut, Difa SS dan semen dari berat kering tanah.

\begin{tabular}{rl}
\hline Variasi & \multicolumn{1}{c}{ Deskripsi Tanah } \\
\hline 1 & $100 \%$ tanah gambut \\
3 & $96 \%$ Tanah Gambut $+2 \%$ Difa SS $+4 \%$ Semen \\
4 & $98 \%$ Tanah Gambut $+4 \%$ Difa SS $+2 \%$ Semen \\
5 & Tanah Gambut $94 \%+4 \%$ Difa SS $+6 \%$ Semen \\
& Tanah Gambut $96 \%+6 \%$ Difa SS $+4 \%$ Semen
\end{tabular}

Pengubah yang diamati antara lain pengujian karakteristik fisik yang meliputi uji kadar air, berat jenis, batas konsistensi tanah, dan analisis ukuran butiran. Sedangkan pengujian karakteristik mekanik meliputi uji standar proctor (Berat volume tanah kering maksimum dan kadar air optimum) dan uji CBR. Pengujian CBR dilakukan tanpa rendaman (unsoaked) karena kadar air sampel tanah gambut sangat tinggi, dengan lama perawatan sebelum pengujian 4 hari.

\section{HASIL DAN PEMBAHASAN}

Hasil pengujian sifat fisik dan pemadatan untuk setiap variasi tanah disajikan pada tabel 2 .

Tabel 2. . Hasil pengujian fisik dan mekanis tanah

\begin{tabular}{lccccc}
\hline \multicolumn{1}{c}{ Deskripsi Tanah } & w (\%) & Gs & $\gamma \mathbf{d}_{\text {max }}$ & $\mathbf{w}_{\text {opt }}(\boldsymbol{\%})$ & CBR (\%) \\
\hline $100 \%$ tanah gambut & 182,85 & 1,27 & 1,68 & 17 & 16,57 \\
\hline $\begin{array}{l}96 \% \text { Tanah Gambut + 2\% Difa SS + 4\% } \\
\text { Semen }\end{array}$ & 15,61 & 1,11 & 0,85 & 19,2 & 38,66 \\
\hline $\begin{array}{l}\text { 98\% Tanah Gambut + 4\% Difa SS + 2\% } \\
\text { Semen }\end{array}$ & 7,17 & 1,29 & 0,93 & 11,8 & 40,87 \\
\hline $\begin{array}{l}\text { Tanah Gambut 94\% + 4\% Difa SS + 6\% } \\
\text { Semen }\end{array}$ & 11,82 & 1,22 & 0,76 & 18,2 & 43,24 \\
\hline $\begin{array}{l}\text { Tanah Gambut 96\% + 6\% Difa SS + 4\% } \\
\text { Semen }\end{array}$ & 8,95 & 1,55 & 0,79 & 16 & 45,29 \\
\hline
\end{tabular}

1. Indeks Propertis Tanah

Pengujian Tingginya kadar air tanah gambut asli kondisi lapangan memperlemah daya dukung tanah, dengan penambahan Difa SS dan semen di setiap variasi campuran menyebabkan 
berat jenis campuran mengalami peningkatan dan kadar air menurun, karena kedua bahan tambahan tersebut mengisi pori pori tanah gambut dan air yang terkandung di dalamnya akan keluar.

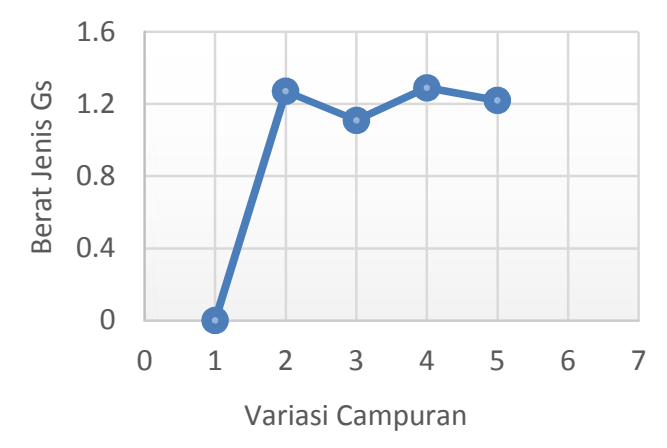

Gambar 1. Hubungan Berat Jenis terhadap variasi campuran

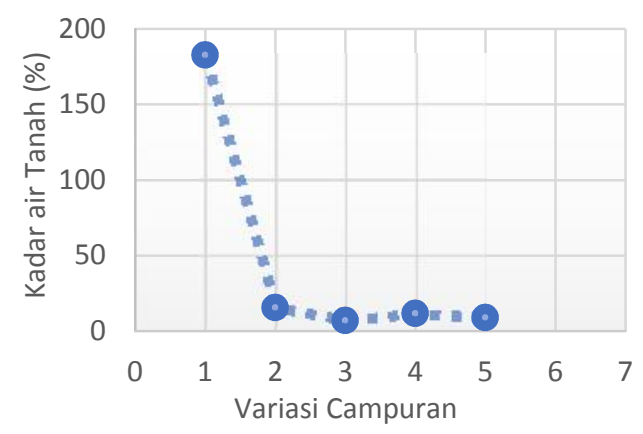

Gambar 2. Hubungan kadar air dan variasi campuran

\section{Pemadatan Standard Proctor}

Gambar 3 menunjukkan kenaikan kepadatan kering maksimum seiring dengan penambahan variasi campuran stabilisasi.

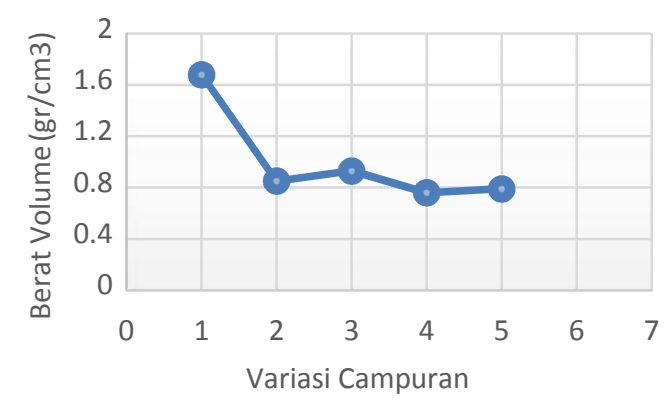

Gambar 3. Hubungan Berat Volume Tanah dengan Variasi Campuran
Kenaikan berat volume kering maksimum disebabkan terjadinya peningkatan berat jenis campuran. Proses hidrasi semen membutuhkan air yang akan diserap semen untuk membantu proses hidrasi yang akan terjadi.

\section{Nilai CBR Tanah dengan Penambahan Semen dan Difa SS}

Pada Gambar 4 menunjukkan, semakin banyak penggunaan Difa SS pada sebuah campuran, akan memberikan nilai daya dukung yang lebih tinggi, hal ini disebabkan Difa SS dapat melarutkan asam humus pada permukaan butiran tanah, mengakibatkan semen dapat mengikat kuat pada partikel tanah. Disisi lain komponen pembangunan stabilitasi tanah Difa SS membentuk kristal-kristal tiga dimensi yang kokoh.

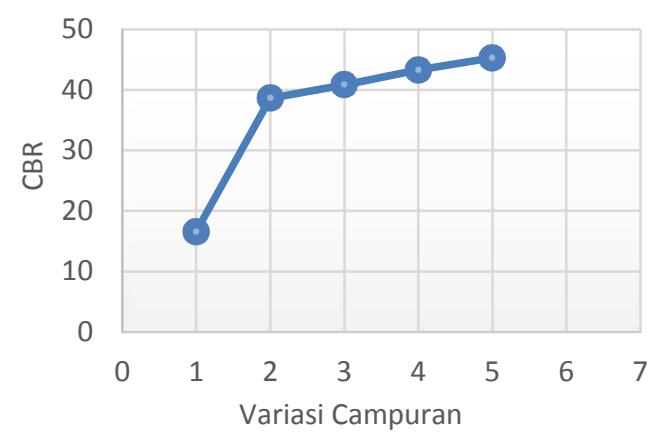

Gambar 4. Hubungan CBR dengan

$$
\text { Variasi Campuran }
$$

Dari hasil pengujian, nilai CBR pada tanah gambut cukup tinggi hingga mencapai $45,29 \%$ untuk variasi $6 \%$ Difa SS dan $4 \%$ Semen. Hal ini disebabkan karna gambut yang digunakan kandungan pasirnya lebih banyak berdasarkan hasil Analisa saringan. Butiran lolos saringan no $200=0,42 \%$ dan yang tertahan di saringan no $200=$ $99,58 \%$.

Sedangkan pada variasi campuran yang menggunakan Difa SS lebih sedikit dari penggunaan semen nilai CBR yang dihasilkan pun lebih rendah. Dari 
pengujian batas konsistensi tanah di dapat plastisitas indeks (PI) 21,17\%.

\section{KESIMPULAN}

Kesimpulan yang didapat dari penelitian ini yaitu Penggunaan campuran Difa SS dan Semen dapat merubah sifat sifat fisik dan mekanik pada tanah gambut. Hal ini terlihat dengan naiknya nilai CBR pada tanah gambut berpasir (tanah dasar) dengan lama waktu perawatan atau pengeraman selama 4 hari, kapasitas daya dukung tanah gambut meningkat. Meningkatnya kapasitas dukung tanah pada tanah gambut dapat mengatasi permasalahan selama ini untuk menjadikan tanah gambut sebagai subgrade pada pekerjaan jalan tanpa harus membuang atau menganti dengan material tanah timbun.

\section{DAFTAR PUSTAKA}

Andriani, Yuliet R, Fernandez L.F . (2012) Pengaruh Penggunaan Semen Sebagai Bahan Stabilisasi Pada Tanah Lempung Daerah Lambung Bukit Terhadap Nilai Cbr Tanah." Jurnal Rekayasa Sipil 8(1): 29-44.

https://doi.org/10.25077/jrs.8.1.2944.2012

Kristiadi, A., and Marzuko,A. (2016). Pengaruh Penambahan Bahan Additif Berupa Campuran Semen Dengan Difa SS Pada Tanah Butir halus Terhadap Nilai CBR (California Bearing Ratio). Jurnal Teknik Sipil, Universitas Islam Indonesia: 1-11.

Mahakarya, PT. Difa. (2012). PT . Difa Mahakarya Profile Product.

Mochtar, N.E. Yulianto, F.E., Rendy. T.S. (2014). Pengaruh Usia Stabilisasi Pada Tanah Gambut
Berserat Yang Distabilisasi Dengan Campuran CaCO 3 dan Pozolan. Jurnal Teoritis dan Terapan Bidang Rekayasa Sipil 21(1): 5764.

Muqorrobin, Dkk. (2018). Stabilisasi Tanah Lempung Organik Menggunakan Semen Dan Difa Soil Stabilizer. Jom Fteknik Universitas Riau 5(2): 1-6.

Nugroho, Soewignjo Agus. (2012). "Riau Peat Stabilisation Using Mix Non Organics Oil And Cement As Road Fills Stabilisasi Tanah Gambut Riau Menggunakan Campuran Tanah Non Organik." Dinamika Teknik Sipil 12(2): 15156.

Pirmadona. (2015). "Stabilitas Tanah Plastisitas Rendah Dengan Semen." Jom Fteknik 2(2): 1-11.

Srihandayani, S. (2017). "Pengaruh Tanah Ekspasif Pada Bangunan Sipil dan Solusinya." Unitek Sekolah Tinggi Teknologi Dumai 10.

Sudjianto, Agus Tugas. (2007). "Stabilisasi Tanah Lempung Ekspansif Dengan Garam Dapur ( $\mathrm{NaCl}$ )." Teknik Sipil 8(3): 53-63.

Tifani, Efan. 2019. "Laju Pemampatan Tanah Gambut Melalui Pengujian Konsolidasi Primer ( Studi Kasus : Tanah Gambut , Desa Tanjung Leban , Propinsi Riau )." JSIL Jurnal Teknik Sipil dan Lingkungan, Teknik, Jurusan Poloteknik, Sipil Bengkalis, Negeri Alam, Sungai 04(01): 19-26.

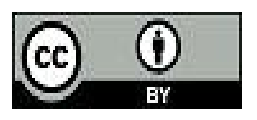

(C) 2019 Siklus: Jurnal Teknik Sipil All rights reserved. This is an open access article distributed under the terms of the CC BY License (http://creativecommons.org/licenses/by/4.0/) 